\title{
THE FATE OF JOHANNES SAMBUCUS' LIBRARY
}

\author{
NOÉMI VISKOLCZ \\ University of Miskolc \\ bolvnoemi@uni-miskolc.hu
}

\begin{abstract}
Some of the manuscripts and books of the Hungarian humanist, Johannes Sambucus (1531-1584) are still kept in Vienna, in the Austrian National Library. A source of information puts a new light on the sale and reception of his library. In his last will made in 1583, Sambucus left his library, the manuscripts he still owned and his maps to his son, in 1584, not long after his death, his widow started negotiations about selling them to the Emperor Rudolf II. However, the data clearly suggest that Sambucus' library did not become en bloc part of the Imperial Library, if the purchase took place at all: only 44 years after Sambucus' death was a certain part of his library bought by Sebastian Tengnagel for both the Imperial Library and himself. Another result of the research confirms that the philologist Sambucus cannot be separated from the book and manuscript collector Sambucus, and the examples presented here justify why it is worth involving in the research the extant books of the Hungarian humanist.
\end{abstract}

Keywords: Johannes Sambucus, library, Sebastian Tengnagel, Humanism, Greek language books, Hofbibliothek, Vienna

Some of the manuscripts and books of the Hungarian humanist, Johannes Sambucus (1531-1584) are still kept in Vienna in the Austrian National Library. Hans Gerstinger, Pál Gulyás, Franz Unterkircher, and recently Gábor Almási have all intensively studied the fate of Sambucus' manuscripts and books, and the history of the library, ${ }^{1}$ which can be summarised as follows: due to his dire financial situation, in 1570 Sambucus had already offered part of his valuable manuscripts -360 of which were written in Greek (including several unpublished texts) and 140 in Latin - to emperor Maximilian I, asking 5 ducats for each volume and a total of 2500 ducats. However, the sale was implemented only in 1578, after Rudolf II had ascended the throne, and no list of the manuscripts has been preserved. Although in his last will made in 1583, Sambucus left his library, the manuscripts he still owned and his maps to his son, in 1584, not long after his death, his widow started negotiations about selling them to the King. Eventually, the collection was evaluated and the price was determined in 1587 with the help of imperial librarian Hugo Blotius (1533-1608). The original catalogue compiled at that time and containing 2618 items was lost, but a copy of it was found in Venice and published by Pál Gulyás in $1941 .^{2}$ We have no further sources providing 
information about the transportation and the placement of the library. While a significant part of Sambucus' manuscripts could be identified, the same cannot be said about the printed part of the library. In the 1930s Pál Gulyás managed to find the shelf marks in the card catalogue of the Austrian National Library and also made efforts to hold the volumes in his hands, doing excellent work considering the research opportunities of the era. However, he could not finish his research. ${ }^{3}$

When during my research work in Vienna I was browsing through some of the documents (catalogues, correspondences, records) concerning the history at the beginning of Early Modern Times of what was once the Hofbibliothek, I came upon a source of information that put a new light on the sale and reception of the library in 1587 , which had previously seemed rather obvious. The following subtitle can be read in the catalogue of the private library of imperial librarian Sebastian Tengnagel (1563-1636): In hypocausto paruo versus Danubium, e Sambucianis, which means that in a small room in the Danube side of his house he kept Sambucus' books.

\section{Sebastian Tengnagel}

Tengnagel, who was of Dutch origin, was employed in the Imperial Library in 1602 as an assistant to Hugo Blotius, and then, from 1608 - after Blotius' death - as the head of the library. Besides the first significant systemisation and cataloguing, the relocation of the library to a new, bigger location is also related to his name. His linguistic talents were proven not only by the 15 languages that he was able to speak, but also by his passionate interest in Eastern languages. He made efforts to acquire as many Arabic, Persian, Turkish, Syrian and even Ethiopian manuscripts as possible. ${ }^{4}$

As for his books, he decided already in 1609 to leave them to the Imperial Library and confirmed this intention in his last will in 1633. Two catalogues of the collection of his library, handwritten by him have survived, of which the later one groups the books in his house according to their locations. The books of Sambucus were kept in the small room at the Danube side. ${ }^{5}$

Before going into the details of this latter, first the question of how Sambucus' books ended up at Tengnagel needs to be answered. It has already been noticed by both Hans Gerstinger and Pál Gulyás that inscriptions of Sambucus and Tengnagel appear together in several manuscripts. Gerstinger refers to a letter written by Tengnagel in 1620, according to which a part of the Sambucus collection had not yet been sold and there was not really any interest in it either, and also, the title page of one of the Greek language manuscripts has the inscription that Tengnagel bought it "e Bibliotheca Sambuci" in 1628. ${ }^{6}$ Gerstinger thinks that those manuscripts were either acquired by Sambucus after 1578 or were being lent to someone 
for publication during the period of the sale in 1578, and he also lists 42 inscriptions found in Sambucus' manuscripts possessed by Tengnagel. ${ }^{7}$ An important characteristic of these manuscripts is that they are all written in Greek. Another two Greek manuscripts were added by Hermann Menhardt in 1957, making the number of the "common" manuscripts that we now know of $44 .{ }^{8}$ Comparing Gerstinger's list with the manuscript items of Sambucus' library, it is apparent that Tengnagel obtained from the heirs the majority of the remaining Greek language codices. ${ }^{9}$

Pál Gulyás also noticed already that it was not only manuscripts, but also books that were acquired by Tengnagel; he listed the latter as notes at certain parts of the library catalogue published. ${ }^{10}$ István Bálint Nagy believes that Tengnagel, taking advantage of the difficulties of Sambucus' son, who was somewhat weak-minded, and his protector, might have bought the books for the Emperor for a very low price, 400 forints, instead of the original estimated value of 3000 forints, and retained a certain part for himself. ${ }^{11}$ However, some information, so far unknown in the relevant Hungarian literature, offers another possibility concerning the fate of the library: Sambucus' widow, Christina Egerer, made a testament in 1609 and bequeathed the library to Niclas Haunoldt, called "cousin" (Gevater). ${ }^{12}$ Haunoldt worked as a secretary at the Royal Chamber, he was a member of several delegations to Turkey and wrote a historical work. ${ }^{13}$ When, following Haunoldt's death, the library was again offered for sale, Tengnagel had the opportunity to cherrypick some books. According to his records, the items were not purchased on one occasion: he indicated $1628^{14}$ and 1631 as the date of acquisition on the cover of a manuscript and a printed item, respectively (item 59). Consequently, it is not yet clear what happened to Sambucus' library after his death and we need to involve further sources to be able to reveal it.

\section{The Tengnagel catalogue}

This source is a manuscript containing Tengnagel's own records about the imperial library and his own library (in the latter case with the following chapter titles: Catalogus librorum in hypocausto meo magno; Catalogus librorum in hypocausto paruo versus Danubium; Libri Gallici, Italici, Hispanici, et Portugallici in hypocausto paruo versus Danubium) where he also describes the Sambucus books under the following title: In hypocausto paruo versus Danubium, e Sambucianis. ${ }^{15}$ This is followed by a list of Greek manuscripts with 83 items (Libri Manuscripti Graece). Here, however, Tengnagel only mentions about two codices that they originate from Sambucus. ${ }^{16}$

The catalogue of Sambucus' books contains 56 books, all of which are printed (Tengnagel erroneously counted 47 items at the end - Numerus Sambucianorum librorum 47). He handled the books following the principle of provenance and 
did not unite them with the other parts of his library, but kept them separately, in a small room. Some of the 56 items are "Sammelbände" (two or more works in one volume), and the number of works they include is 97 . These volumes were probably ordered to be bound together by Sambucus, who sometimes even numbered the title pages of the consecutive works (item 21), or he also may have bought them already bound together. In composite volumes the works are usually not related concerning their authors, subject matter or publishers, so it seems that Sambucus only considered the size (if he himself had the volumes bound together). We must also add that in the $18^{\text {th }}$ century, the composite volumes were disassembled in the Imperial Library, during which the original inscriptions were often damaged and the old bindings were replaced by more modern and simpler, half leather or paper bindings.

The descriptions of items in Tengnagel's handwriting contain the authors, titles and publishers of the works, the date and place of their publications, the printing house and the format of the works. Sometimes there are errors in the documentation, for example the year of the publication is wrong, or, on a few occasions, an inner piece of the composite volume escaped Tengnagel's attention. In several cases there are additional remarks to the items, where he mentions for example that a certain work was edited by Sambucus on the basis of old codices, with commentaries (items 1 and 2); or, he mentioned that a book originates from Andreas Dudith's library (item 31); or that it contained the handwritten notes of Sambucus (item 37). Throughout the catalogue, notes about the library shelf marks of certain volumes written in pencil by a $20^{\text {th }}$ century person appear.

In the case of 22 items, Sambucus' ownership can be proven on the basis of the book-plate or the handwriting; his name appears in different forms, just like in the manuscripts: ${ }^{17}$ J. Sambuci, Joan. Sambucus, Ex libris J. Sambucus P., Joannis Sambuci Pannonij Tirnauien. It has become also clear that Sambucus did not enter his name in all the books; however, there seems to be no system in where and why he wrote his name. Tengnagel's notes appear in 24 cases, with less variety than Sambucus', usually in the following form: Ex libris Sebastiani Tengnagelij I. V. D. Consiliar. et Bibliothec. Caesar. Most of the works listed in the register also appear in the catalogue published by Pál Gulyás, but there are also a few exceptions (for example items 27 and 46 are not listed). Today all the books are available in the Austrian National Library, but in some cases, their known provenance indicates that they could not have belonged to either Sambucus or Tengnagel. Throughout the centuries, the Imperial Library was weeded several times, and the duplicated volumes were given away to other libraries. ${ }^{18}$ No specific referencing which could lead to conclusions about the classification schemes or other arrangement of his library appears in Sambucus' books.

Entries that go beyond the owner's inscriptions and provide more information than just the name are especially valuable. The liturgical work of John Chrysos- 
tom written in Greek and published in Rome in 1526 was bought by Sambucus in Verona in 1560 (item 26). He obtained De Proprietate Sermonum by Nonius Marcellus from Hadrianus Junius, who actually published it in Antwerp at Plantin in 1665 (item 40). On the title page Sambucus added the somewhat malicious remark to the title that not only Junius' but also his own hard work was needed to achieve this. This was not only mentioned by Junius in the letter of dedication addressed to Maximilian II ("vti locuples testis et quidem T.M. domesticus, Ioannes Sambucus mihi indicium fecit") - the Hungarian man meticulously underlined his own name here -, but subsequently, he also saluted Sambucus with a dedication addressed to him. Junius, the esteemed Dutch philologist participated in the implementation of the publishing programme of Sambucus, and at that point, in the middle of the 1560 s, their collaboration seemed still harmonious. ${ }^{19}$

Returning to the notes, on the title page of the work of Aeschylus published in 1552 in Venice (item 57) it appears that Sambucus bought it for 7 crowns in 1559 and emended it in Rome. There are two books that Sambucus obtained in Paris in 1551 from the library of the esteemed French Hellenist, Jacques Toussain. ${ }^{20}$ At least Tengnagel notes on the cover pages that both volumes belonged to the celebrated professor, but we do not know where that information came from. The volumes are in fact important Aldines; the work by Thucydides was published in 1502 and the one by Ulpianus in 1503, both in Venice. Tengnagel obtained the latter in 1631. A third Aldine edition originates from the library of the Hellenist Jean Strazel, also from Paris (item 61), from where Sambucus also bought a Polybius manuscript for four ducats. ${ }^{21}$ The Hungarian humanist entered a lot of notes in the Greek or Greek-Latin language volumes, as opposed to Tengnagel, who only rarely made comments and whose neat and easily legible handwriting can be found for example in the work about Saint Peter's peregrination (item 12).

However, Tengnagel's catalogue was far from complete, as beyond the 56 items indicated, I also found eight other Greek language printed volumes in the Austrian National Library which contain inscriptions of both Sambucus and Tengnagel (items 57-64).

\section{The subject matter of the books}

The catalogue suggests that Tengnagel, whose aim was probably to make up for the deficiencies of his library, obtained books in the widest range of topics: he equally selected books from the fields of theology, medicine, history, philology, philosophy and literature and geography. His interest in Greek language editions is obvious, as the proportion of Greek/Greek-Latin and Latin works is about the same. The oldest work is a volume printed in Florence in 1494, while the latest were produced in 1582 and come from Basel and Antwerp. 
The volume of dramas by Aeschylus published in Paris in 1552 indicated in the catalogue is especially exciting (item 57). The first printed Aeschylus edition appeared in Venice. Aldus Manutius was very keen on publishing the tragedies with commentaries, but his death in 1515 prevented it. Eventually, Aldus's father and brother-in-law published it in 1518, but they were severely criticised for the great number of errors. ${ }^{22}$ Following Jean Dorat's Prometheus from 1548, in 1552 two complete editions were published. The first appeared in Venice, edited by Francesco Robortello, who could probably use the best manuscript of the age in the Medici Library in Florence. Robortello's significant philological contribution was that he separated the intermingled text of two Aeschylus dramas, Agamemnon and The Choephori (Libation Bearers), also indicating the hiatuses by leaving empty spaces in the text for the missing lines, which meant that he was the first editor to publish the seven tragedies (Prometheus, Seven Against Thebes, Persians, Agamemnon, Eumenides, Libation Bearers, Suppliants). However, the book was not a unanimous success, as he was not able to completely reconstruct the two tragedies mentioned.

The other complete edition from 1552 is related to Adrien Turnèbe, as it was the first volume he printed as a royal printer. He published six tragedies, and even if he knew Robortello's work, he did not take it into consideration. The best edition of the Aeschylus' works until then appeared in Geneva at Henri Estienne, edited by Piero Vettori, in 1557. It contains the seven tragedies including the reconstructed text of Agamemnon and The Choephori. In his Preface, Vettori calls Aeschylus a unique dramatist, Hermetic philosopher, inspired poet and the greatest of Homer's followers. ${ }^{23}$ There is another remarkable edition from the last third of the century, from Antwerp, by the philologist Wilhelm Canter, who had a good relationship with Sambucus. ${ }^{24}$

From among the editions listed above, only the editio princeps, i.e. the Aldina published in Venice in 1518, was missing from Sambucus' library: besides Prometheus with the Preface of Jean Dorat (Gulyás, 1968), and the complete editions of Francesco Robortello (Gulyás, 659), Turnèbe (Gulyás, 125), Piero Vettori (Gulyás, 1745) and Canter (Gulyás, 2432), the Latin translation of the six tragedies published in Basel in 1555 (Gulyás, 711) and the selection of Greek dramas edited by Estienne in 1567 (Gulyás, 1273) also appear. ${ }^{25}$ We can conclude that Sambucus was well-acquainted with Aeschylus' works printed in the era and the related research.

Although all of these books can be found in the Austrian National Library, only one of them - the one published in Paris in 1552 - can be definitely proven to have belonged to Sambucus, on the basis of the owner's signature (item 57). $\mathrm{He}$ also noted on the title page that he had bought it in 1556 and emended it in Rome. The Greek text has several emendations and Greek or Latin notes by Sambucus. From page 144, where Robortello could not continue the text of 
Agamemnon (the interrupted Greek text is followed by Hic uidentur multa deesse), Sambucus inserted new sheets and he himself supplemented the drama in handwriting, with his own page numbering until page 169 . The printed text continues from there; however, Sambucus crossed out the original page number (145) and replaced it by 169 . There is also another insertion of similar length added by him: the ending of Agamemnon with his own numbering between pages 172 and 192.

Philologists will be able to examine the type and depth of the emendations and additions, and whether Sambucus relied on a manuscript from Rome (an Aeschylus manuscript was kept in Alessandro Farnese's library $)^{26}$ or some other source. Later on, he was still interested in Aeschylus: in April 1569, he wrote to Piero Vettori $^{27}$ that he had found a very old manuscript with Aeschylus' dramas, including The Choephori and that he wished Vettori would edit the tragedy on the basis of the manuscript. ${ }^{28}$ And in 1574 he mentioned to him that he had already sent to Plantin the notes (scholia) of Triklinios and Thomas Magister - a Byzantine monk and scholar - on Aeschylus. ${ }^{29}$

\section{Sambucus' books outside the Austrian National Library}

Apart from Tengnagel's purchase, the dispersal of part of Sambucus' library is also supported by other data. A book has appeared in the Library of the University of Vienna - the Florilegium Diversorum Epigrammatum (Paris, 1531) - , ${ }^{30}$ on whose title page, above Sambucus' handwriting there is a note saying Bibliothecae Windhagianae Catalogo inscriptus 1667. ${ }^{31}$ Joachim Enzmilner, the Count of Windhag (1600-1678) obtained several manuscripts and books in the 1660s from what was once Sambucus' library, in a way that has so far been unknown. ${ }^{32}$ Matthias Bernegger kept some unpublished mathematical manuscripts from Sambucus' heritage. ${ }^{33}$ Today, some other libraries also have books once belonging to Sambucus: there is a copy of Copernicus' De revolutionibus at the Library of the Debrecen Trans-Tisza District of the Hungarian Reformed Church, ${ }^{34}$ a Neoplatonic work at the University Library of Eötvös Loránd University (which earlier belonged to the Archbishop's Library in Vienna), ${ }^{35}$ a Bonfini book edited by Sambucus in 1568 at the Library of the Hungarian Academy of Sciences, ${ }^{36}$ an incunabulum at the University Library of Erlangen (Herbarius latinus, Main, 1484), and a Dioscorides in Chantilly. ${ }^{37}$

\section{Quantitative data concerning Sambucus' library - once again}

In the relevant literature, there are a number of data about the volume of Sambucus' manuscripts and library, which often contradict one another. It is rather 
difficult to determine the exact numbers since already at the sale in 1578, Sambucus himself mentions at one point handing over 500 and at another point 530 manuscripts. ${ }^{38}$ Moreover, some manuscripts of Sambucus found their way to the Imperial Library following Tengnagel's death (1636), and also during the $18^{\text {th }}$ century, which increased the number to nearly 600 . It is even more difficult to decide how many manuscripts have been identified. In the case of printed books, the catalogue is the starting point, but even here special attention must be paid to the composite volumes and the notes when for example he has ten copies of a certain work.

It is worth clarifying on the basis of the extant catalogue that Sambucus handled together the printed books and the manuscripts. In the case of the items indicated by serial numbers, the manuscripts can be identified since they were indicated by the person registering them as manuscript., manuscriptus. These manuscripts were catalogued among the printed books, although they were mostly listed collectively, in a block (for example Gulyás, items 1095-1134 and 2549-2618), but it also happened that there was a "Biblia sacra manuscripta in $8^{\circ}$ Latine" (Gulyás, 972) among the printed Bibles. This was not a strange practice at the age and in the Imperial Library Tengnagel was the first person to try and separate the manuscripts from the printed books. ${ }^{39}$

On the basis of the published library catalogue, Pál Gulyás had some remarks about the data concerning Sambucus' library: "indeed in the Venice copy the inventory extending to 279 folio leaves contains 2618 serial numbers, which, however, does not mean at all that the heritage consists of the same number of books", 40 and later "according to the inventory, at his death, Sambucus owned no less than 3327 volumes of 3163 printed books (and 78 multiple copies among those), 128 pieces of 28 score editions and 206 volumes of manuscripts. ${ }^{41}$ I do not think anybody has so far doubted the data of Pál Gulyás, but recounting has produced different results. The catalogue registered with serial numbers has a lot of errors made, on the one hand, by those registering the items, and, on the other, by Pál Gulyás. On a few occasions the registering persons did not write down the title next to the serial number (Gulyás, 58, 108, 110-112, 120, 1384), and Gulyás omitted some items (Gulyás, 54, 301, 890-899, 1402, 1656, 1719, 1793, 2145), and in one case, also added an item (1312 is listed twice, once also after 1319). According to the catalogue, Sambucus had more than one copy of two books: ten copies of one (Gulyás, 2184), and six of the other (Gulyás, 2231). All the above taken into consideration, the 1587 catalogue yields the following numbers:

- printed books: 3501

- manuscripts: 207

- cannot be decided: 4

- music prints: 103 


\begin{tabular}{lll}
\hline & $\begin{array}{l}\text { Manuscripts sold } \\
\text { in } 1578\end{array}$ & $\begin{array}{l}\text { Collection of his library } \\
\text { in } 1587\end{array}$ \\
\hline & $\begin{array}{l}360 \text { Greek } \\
\text { 140 Latin } \\
\text { 30 where language } \\
\text { is not specified }\end{array}$ & 207 \\
Manuscripts & & 3501 \\
Printed books & & 103 \\
$\begin{array}{l}\text { Sheet music (prints) } \\
\text { Not clarified whether printed books or } \\
\text { manuscripts }\end{array}$ & & 4 \\
\hline Total & 530 & 3815
\end{tabular}

Further clarifications can also be provided about Sambucus' manuscripts, with the remark that new manuscripts may be found at any time. Of his manuscripts

- he donated 9 to the emperor before 1578;

- he sold 530 to Emperor Rudolph II in 1578;

- 207 were in his library in 1587, of which some of the Greek language items found their way to the Imperial Library through Tengnagel;

- we also know about some external items (at editors, printing houses, friends); the number of these is unknown.

Apart from the work done by Peter Lambeck and the imperial librarian following him in the $18^{\text {th }}$ century, the manuscripts were identified in the $20^{\text {th }}$ century by Hans Gerstinger, who by 1926 had determined about 497 manuscripts that they belonged to Sambucus. ${ }^{42}$ At the beginning of the 1950s Hermann Menhardt revealed meticulously Sambucus' ownership of 69 further codices. ${ }^{43}$ István Németh, who worked at the Austrian National Library and died recently, also studied Sambucus' manuscripts, but did not publish his results. Gábor Almási and Gábor Kiss Farkas have recently published the shelf marks of the 88 manuscripts discovered by Németh. ${ }^{44}$ However, Németh failed to notice Menhardt's findings and in part only repeated the latter's results, and therefore only 38 of his manuscript identifications can be considered as new data. Finally, we must also mention that similarly to the printed books, also some manuscripts were taken away from Vienna and can now be found in different European collections. 


\begin{tabular}{|c|c|c|c|c|c|}
\hline $\begin{array}{l}\text { Gerstinger / } \\
\text { identified at } \\
\text { the ÖNB }\end{array}$ & $\begin{array}{l}\text { Menhardt / } \\
\text { identified at } \\
\text { the ÖNB }\end{array}$ & $\begin{array}{l}\text { Németh / } \\
\text { identified at } \\
\text { the ÖNB }\end{array}$ & $\begin{array}{l}\text { Gerstinger } \\
\text { / identified } \\
\text { outside the } \\
\text { ÖNB }\end{array}$ & $\begin{array}{l}\text { Almási-Kiss } \\
\text { / identified } \\
\text { outside the } \\
\text { ÖNB }\end{array}$ & Other data ${ }^{45}$ \\
\hline $\begin{array}{l}384 \text { Greek } \\
113 \text { Latin }\end{array}$ & $\begin{array}{l}31 \text { Greek } \\
37 \text { Latin } \\
+1 \text { Latin } \\
\text { delivered to } \\
\text { Hungary in } \\
1933\end{array}$ & $\begin{array}{l}26 \text { Greek } \\
12 \text { Latin }\end{array}$ & 6 & 6 & unidentifiable \\
\hline 497 & 69 & 38 & 6 & 6 & \\
\hline
\end{tabular}

Total: 616 manuscripts

\section{Summary}

The data clearly suggest that Sambucus' library did not become en bloc part of the Imperial Library, if the purchase took place at all. If we trust Tengnagel's letter mentioned above and also accept the other data presented, it took almost 30 years following Sambucus' death for the collection or certain parts of it to be obtained by a new owner, and finally Tengnagel bought some of it for both the Imperial Library and himself. A number of Sambucus' printed books and manuscripts could reach the Imperial Library only through alternative ways during the $17^{\text {th }}$ and $18^{\text {th }}$ centuries.

Following the random examination of the printed volumes in the Sambucus catalogue, as well as their study on the basis of Tengnagel's register, it is obvious that the books kept today in the Austrian National Library, mostly in one copy, can only be proven to have been in Sambucus' possession if this assumption is reinforced by his inscription or the characteristic features of his handwriting. The activities of Sambucus the philologist cannot be separated from those of Sambucus the collector of manuscripts and books, and the examples presented here justify why it is worth involving in the research the extant books of the Hungarian humanist.

\section{Notes}

1 Hans Gerstinger, Johannes Sambucus als Handschriftensammler. - In: Festschrift der Nationalbibliothek in Wien zur Feier des 200jährigen Bestehens des Gebäudes, hrsg. von Österreichischer Nationalbibliothek (Wien: Österreichische Nationalbibliothek, 1926), 279-288.; Gulyás, Pál, Bibliotheca Joannis Sambuci. Sámboky János könyvtára (Budapest: author's edition, 1941), 27-29.; Franz Unterkircher, Hugo Blotius und seine ersten Nachfolger (1575-1663). 
- In: Stummvoll, Josef (Hg.) Geschichte der Österrechischen Nationalbibliothek, Bd. 1. (Wien: Österreichische Nationalbibliothek, 1968), 82-120.; Gábor Almási, The Uses of Humanism. Johannes Sambucus (1531-1584), Andreas Dudith (1533-1589), and the Republic of Letters in East Central Europe (Leiden-Boston, Brill, 2009), 193-196.

2 Gulyás 1941, new edition: Gulyás, Pál, A Zsámboky-könyvtár katalógusa, 1587, ed. Monok, István (Szeged: Scriptum, 1992).

3 Gulyás 1941, 30.

4 Unterkircher 1968, 129-145.

5 Unterkircher 1968, 142-143.

6 Gerstinger 1926, 288., Gulyás 1941, 30.

7 Gerstinger 1926, 346.

8 Hermann Menhardt, Das älteste Handschriftenverzeichnis der Wiener Hofbibliothek von Hugo Blotius 1576. Kritische Ausgabe der Handschrift Series nova 4451 vom Jahre 1597 mit vier Anhängen (Wien: Rohrer, 1957) (Denkschriften der Akademie der Wissenschaften in Wien. Phil.-hist. Kl.; Bd. 76), 24.

9 There is a need for further research.

10 Gulyás found 3 books, in which a handwritten inscription of Zsámboky and Tengnagel together could be read, see Gulyás 1941, items 152., 659., 1644.

11 Bálint-Nagy István, „Sámboky János (1531-1584) orvosi müködéséről” Az Orvosi Hetilap Tudományos Közleményei, 1929, 26.

12 Franz Wilflingseder, „Geschichte des einstigen Freisitzes Egereck in Linz“, Jahrbuch der Stadt Linz, 1954, 462.

13 He is one of the authors of Johannes Löwenklau's work Neuwe Chronica Türckischer Nation (Frankfurt am Main, 1590), see Der Preis der Diplomatie. Die Abrechnungen der kaiserlichen Gesandten an der Hohen Pforte, 1580-1583, ed. Graf, Tobias P. (Heidelberg: Universitätsbibliothek, Heidelberg, 2016), 9:63

14 Gerstinger 1926, 288.

15 Österreichische Nationalbibliothek, Sammlungen von Handschriften und alten Drucken, Cod. 12650, f. 60-64. The Tengnagel book catalogue is edited In: - Magyarországi magánkönyvtárak IV, 1552-1740, ed. Bajáki, Rita - Bujdosó, Hajnalka - Monok, István - Viskolcz, Noémi (Budapest: OSZK, 2009) (Adattár XVI-XVIII. századi szellemi mozgalmainak történetéhez,13/4), 11-18.

16 Idem, f. 83r. 37. Georgij Pachymeris Epitomae Philosophiae Aristotelicae Libri XII. Philippus Bechius Medicus Basiliens. Olim illum vertit., ex vitiois exemplarib. hic vero Codex multo correctior et integrior, teste Sambuco, est. In $4^{\circ}$ magno, elegant scriptura; f.86r. 76. Michaelis Choniatae Oratio in Imperatorem Isaacium Angelum, Eiusd. Michaelis Monodia in fratrem suum Nicetan Choniatem. Gregorij Palamae Disputatio inter animam et corpus, quae hic a Sambuco eidem Coniatae attribuit. fol. charta

17 Gerstinger 1926, 256-257.

18 Geschichte der Österrechischen Nationalbibliothek, Stummvoll, Josef (Hg.), Bd. 2., 192., 255-256., 294-295.

19 Almási, Gábor-Kiss, Farkas Gábor, „Szöveggondozás és kapcsolatápolás. Zsámboky János életmüve a reneszánsz filológia tükrében”, Irodalomtörténeti Közlemények 117(2013), 673-676.

20 Toussain was appointed to the professorship of Greek in 1530 at the French royal college, his successor was Adrien Turnèbe, see Peter G. Bietenholz, Jacques Toussain. - In: Contemporaries of Erasmus. A Biographical Register of the Renaissance and Reformation, Vol. 3., ed. Peter G. Bietenholz (Toronto-Buffalo-London: University of Toronto Press, 1986), 336-338.

21 Gerstinger 1926, 310. 
22 John Lewis, Adrien Turnebe (1512-1565) a Humanist observed (Genève: Librairie Droz S.A., 1998), 120-121.

23 Lewis 1998, 124.

24 Almási-Kiss 2013, 680-682.

25 The Aeschylus-editions were mentioned also by Gulyás, see Gulyás 1941, 85.

26 Walter Spoerri, „Die Edition der Aischylosscholien“ Museum Helveticum 37(1980), 15.

27 To the relationship of Vettori and Zsámboky see Almási-Kiss 2013, 655-656.

28 János Zsámboky to Piero Vettori, 06.04.1569. see Hans Gerstinger, Die Briefe des Johannes Sambucus (Zsamboky) 1554-1584. Mit einem Anhang die Sambucusbriefe im Kreisarchiv von Trnava von Anton Vantuch (Wien: Böhlau, 1968) (Österreichische Akademie der Wissenschaften Philosophisch-Historische Klasse Sitzungsberichte, 255. Band), 99.; Spoerri has cast doubt on the theory of Gerstinger, see Spoerri 1980, 19.

29 János Zsámboky to Piero Vettorinek, 17.12.1574., see Gerstinger 1968, 166.

30 Gulyás 1941, 687.

31 Walpurga Oppeker, „Bucheignerzeichen des Grafen Joachim von Windhag“ Biblos. Beiträge zu Buch, Bibliothek und Schrift 2011/1, 137.

32 Gerstinger 1926, 383.; Gulyás 1941, 255., 772.

33 Charles, Schmidt, Zur Geschichte der ältesten Bibliotheken und der ersten Buchdrucker zu Strassburg (Strasbourg: C. F, Schmidt, 1882), 196. Recited by Monok, István, Magyarország és a magyarok az elszászi könyvkiadásban,1482-1621 (Változások a kiadói politikában - változó országkép). - In: Fehér Lovag. Tanulmányok Csernus Sándor 65. születésnapjára, ed. Gálffy László, Sáringer János (Szeged: SZTE, 2015), 222-223.

34 Borzsák, István, „Ein Copernicus-Exemplar aus der Bibliothek des Joannes Sambucus in Debrecen“ Magyar Könyvszemle 81(1965), 133-134.

35 Knapp Éva, „A budapesti Egyetemi Könyvtár két törzsgyüjteménye - XVI-XVII. századi nem hungaricum nyomtatványok" Könyvtári Figyelö 2012/2., 304-305.

36 Borzsák 1965, 134.

37 Almási-Kiss 2013, 652.

38 On the diverse data see Unterkircher 1968, 118.; Almási-Kiss 2013, 631.

39 Menhardt 1957, 4. and 11.

40 Gulyás 1941, 29.

41 Gulyás 1941, 30.

42 The listing see Gerstinger 1926, 349-394.

43 Menhardt 1957, 22-23.

44 Almási, Gábor - Kiss, Farkas Gábor, Humanistes du Bassin des Carpates II. Johannes Sambucus (Turnhout: Brepols, 2014) (Europa Humanistica), 245.

45 Gerstinger 1926, 395.; Almási-Kiss 2013, 631. Publius Ovidius Naso, Metamorphoseon libri XV (Florence, 15th century) - the elegant codex was dedicated to William V., Duke of Bavaria, by Sambucus in 1572 (today: Bayerische Staatsbibliothek, Clm 927), see Kulturkosmos der Renaissance. Die Gründung des Bayerischen Staatsbibliothek, Fabian, Claudia (Hg.), (Wiesbaden: Harrassowitz, 2008), 72. On the manuscripts of Sambucus see Monok, István, A bázeli, a genfi és a zürichi könyvkiadás hatása a magyarországi szellemi áramlatok történetének alakulására a 16. században a kortárs könyvtárak vizsgálata tükrében. - In: „Kezembe vészem, olvasom és arról elmélkedem". Emlékkönyv Fekete Csaba születésének 75. és könyvtárosi müködésének 50. évfordulójára, ed. Gáborjáni, Szabó Botond, Oláh, Róbert (Debrecen: Tiszántúli Református Egyházkerületi Gyüjtemények, 2015) (A Tiszántúli Református Egyházkerületi Gyüjtemények kiadványai, 2.), 197-198. 